DOI $10.14746 /$ ssp.2014.4.11

\author{
Liana HURSKA-KOWALCZYK
}

Uniwersytet Szczeciński

\title{
Studencka „rewolucja na granicie” w kontekście przemian społeczno-politycznych w Ukraińskiej Socjalistycznej Republice Radzieckiej
}

\section{Wstęp}

d 2 do 17 października 1990 r. w Kijowie na placu Niepodległości (wówczas placu Rewolucji Październikowej) odbyły się masowe protesty studentów przeciwko ostatniemu rządowi komunistycznemu Ukraińskiej Socjalistycznej Republiki Radzieckiej (USRR). Protesty te przybrały postać masowej głodówki studentów i strajku większości uczelni stołecznych oraz miast obwodowych, do których dołączyły szkoły zawodowe, licea ogólnokształcące. Do historii protesty te weszły pod nazwą „rewolucji na granicie”. . Znany publicysta Wachtang Kipiani, ich uczestnik, określa je jako akcję nieposłuszeństwa obywatelskiego (Кіпіані, Українська). W podobny sposób definiuje protesty studenckie ukraiński historyk Ołeksandr Bojko (Бойко, 2003, s. 85). Uczestnicy „rewolucji na granicie” mówili, że swoją akcję protestacyjną wzorują „,na skutecznym działaniu studentów bułgarskich przeciwko władzom komunistycznym" w 1989 r. oraz biorą pod uwage ,krwawe doświadczenia studentów chińskich z placu pekińskiego Tian'anmen", w dniach między 15 kwietnia a 4 czerwca 1989 r. (Кіпіані, Українська). Studenci organizujący akcję byli świadomi, że władze mogą użyć wobec nich siły, a także od razu aresztować ich uczestników (Кулик, Голобуцька, Голобуцький, 2000). $\mathrm{W}$ trakcie akcji protestacyjnej studenci założyli miasteczko namiotowe na placu Rewolucji Październikowej, blokowali ruch drogowy, Radę Najwyższą, główne gmachy uczelni wyższych, przede wszystkim Kijowskiego

12 października 1990 r. o godzinie 10.00 ok. 40 aktywistów Bractwa Studenckiego miasta Lwowa i Ukraińskiego Związku Studentów rozłożyło na granitowych płytach na placu Rewolucji Październikowej (obecnie plac Niepodległości) materace i śpiwory oraz ogłosiło rozpoczęcie głodówki, stąd nazwa protestów studenckich 2-17 października 1990 r. - „rewolucja na granicie”. 
Państwowego Uniwersytetu im. Tarasa Szewczenki, domagając się rozwiązania parlamentu USRR oraz przeprowadzenia ponownych wyborów na zasadzie wielopartyjności; uchwalenia ustawy o nacjonalizacji majątku partii komunistycznej oraz Komsomołu; niedopuszczenia do podpisania nowej umowy o Związku Radzieckim; odbywania służby wojskowej tylko na terytorium Ukrainy; dymisji przewodniczącego Rady Ministrów Witalija Masoła. Głównymi organizatorami protestów studenckich były: Bractwo Studenckie miasta Lwowa oraz Ukraiński Związek Studencki.

Celem artykułu jest analiza fenomenu „rewolucji na granicie” w szerokim kontekście przemian społeczno-politycznych, które zachodziły w USRR, a także w całym Związku Radzieckim przed jego rozpadem. Dla realizacji tego celu autorka wykonała następujące czynności badawcze: wyjaśnienie społeczno-politycznych uwarunkowań „rewolucji na granicie”; ustalenie głównych działań protestacyjnych studentów oraz określenie ich rezultatów. Dla realizacji powyższego celu badawczego zastosowano historyczną metodę genetyczną oraz analizę systemową.

\section{Społeczno-polityczne uwarunkowania ,rewolucji na granicie”}

Sprzyjająca sytuacja dla utworzenia niezależnych organizacji społeczno-politycznych w tym młodzieżowych i organizacji przez nie akcji protestacyjnych wytworzyła się dzięki polityce reform pt. pieriestrojka (przebudowa) zapoczątkowanych przez sekretarza generalnego Komitetu Centralnego Komunistycznej Partii Związku Radzieckiego (KC KPZR) Michaiła Gorbaczowa i jego ekipę w kwietniu 1985 r. Szczególne znaczenie w tym kontekście miała polityka głasnosti (jawności). Oficjalnie polityka głasnosti jako podstawa reform politycznych została zatwierdzona podczas plenum KC KPZR, które odbyło się w styczniu 1987 r. ${ }^{2}$ Procesy zapoczątkowane w 1987 r. odbywały się pod hasłem ,więcej demokracji” i przewidywały przemiany polityczne, których podstawą była polityka głasnosti. Na plenum KC PZPR 27 stycznia 1987 r. M. Gorbaczow w swo-

2 Do powszechnego użytku pojęcie ,głasnost” weszło również w 1987 r. Wprowadzenie polityki głasnosti do środków masowego przekazu wiązano z artykułem Wasilija Polikarpowa w czasopiśmie „Ogoniek” z 1987 r., nr 26, o Fiedorie Raskolnikowie sowieckim działaczu, dyplomacie, który odmówił powrotu z Paryża do Moskwy i zmarł w niewyjaśnionych okolicznościach, jest znany z otwartego listu do Józefa Stalina, w którym potępiał represje w ZSRR. 
im wystąpieniu pt. „O przebudowie i polityce kadrowej partii” stwierdził, że ,przyszedł czas opracować akty prawne, które zagwarantują głasnost”. Zdaniem sekretarza generalnego KC KPZR powinny one zapewnić „,maksymalną otwartość w działalności organizacji państwowych i społecznych, umożliwić pracującym wypowiadanie własnych opinii dotyczących wszystkich kwestii życia społecznego" (O перестройке). Intensyfikacja przemian społeczno-politycznych w ZSRR nastapiła w efekcie decyzji podjętych na XIX Ogólnozwiązkowej Nadzwyczajnej Konferencji Partyjnej, która odbywała się od 28 czerwca do 1 lipca 1988 r. W ostatnim dniu konferencji 1 lipca 1989 r. uchwalono szereg rezolucji, w tym: O demokratyzacji społeczeństwa radzieckiego i reformie systemu politycznego i $O$ głasnosti. Postanowiono, że ,głównym kierunkiem reformy systemu politycznego jest zapewnienie pełni władzy radom deputowanych ludowych jako podstawie socjalistycznej państwowości i samorządności”". Zdecydowano, że organy pochodzące $\mathrm{z}$ wyborów powinny mięć więcej uprawnień, niż „organy wykonawcze oraz ich aparaty”, a „polityka partii - gospodarcza, społeczna, narodowa - powinna być prowadzona przede wszystkim przez przedstawicielskie organy ludowe" (O демократизации). Podczas XIX Ogólnozwiązkowej Konferencji Partyjnej został powołany organ władzy ustawodawczej w ZSRR - Zjazd Deputowanych Ludowych ZSRR. Zjazd Deputowanych z kolei miał wybierać stale działającą Radę Najwyższą ZSRR, zajmującą się zwykłym ustawodawstwem (Медведев, 2010). XIX Konferencja Partyjna podjęła decyzję: 1) zezwalającą na prezentację podczas wyborów alternatywnych programów; 2) o uzawodowieniu deputowanych; 3) nieograniczaniu typowania kandydatów; 4) zaleciła ,ścisłe przestrzeganie demokratycznej procedury wyboru" (19 Всесоюзная). 1 grudnia 1989 r. Rada Najwyższa ZSRR uchwaliła ustawę ZSRR o wyborach deputowanych ludowych ZSRR, a także wprowadziła zmiany do Konstytucji ZSRR z 1977 r. Zgodnie z tą ustawą 26 marca 1989 r. odbyły się pierwsze częściowo wolne wybory deputowanych ludowych ZSRR (Закон).

Do połowy 1987 r. procesy pieriestrojki prawie nie dotknęły Ukraińskiej SRR. Czynnikiem je hamującym, zdaniem historyka Jarosława Hrycaka, była konserwatywna nomenklatura partyjna Komunistycznej Partii Ukrainy (KPU), na której czele stał pierwszy sekretarz KPU Włodzimierz Szczerbicki (maj 1972-wrzesień 1989 r.), prowadzący politykę konsekwentnej intensywnej rusyfikacji USRR (Грицак, 2000, s. 297). Ukraiński politolog Oleksij Harań wskazuje, że konserwatyzm ukraińskiej nomenklatury partyjnej był silniejszy, niż ogólnoradzieckiej (Гончарук, 
Шановська, 2004, s. 80). Z niedowierzaniem przyglądała się ona reformom M. Gorbaczowa, nie śpiesząc się z wprowadzaniem zmian w USRR. Mimo tego począwszy od 1987 r. zarówno w USRR, jak i w pozostałych republikach ZSRR powstawały organizacje nieformalne ${ }^{3}$. Organizowały one w latach 1988-1991 mityngi, wiece, wykorzystując place jako trybunę komunikacji ze społeczeństwem, gdyż większość ogólnorepublikańskich środków masowego przekazu znajdowała się wówczas pod kontrolą KPU. Okres ten w historii Ukrainy określano jako tzw. „demokracja mityngowa”. Pojęcie „demokracja mityngowa” w USRR oznacza aktywność poszczególnych grup społecznych, usiłujących wywierać wpływ na proces decydowania politycznego.

W czerwcu 1989 r. w USRR funkcjonowało około 47 tys. różnych organizacji nieformalnych, wśród nich najwięcej było społeczno-politycznych (6957), ekologicznych (1946) oraz kulturalno-historycznych (1460) (Бойко, 2002, s. 56). We wrześniu 1989 r. w Kijowie została założona największa organizacja nieformalna - Ludowy Ruch Ukrainy na rzecz przebudowy (LRU). LRU połączył w sobie dość szerokie spektrum orientacji społeczno-politycznych - od komunistów-reformatorów do dysydentów i zadeklarował działalność na rzecz odnowienia i demokratyzacji społeczeństwa socjalistycznego (Tpu). Po II zjeździe (25-26 października 1990 r.) LRU stał się największą antykomunistyczną organizacją opozycyjna; z nazwy został wyłączony przydomek „na rzecz przebudowy”; Ruch sprecyzował zasadniczy cel programowy - niepodległość Ukrainy (Гончарук, 1997, s. 90-105).

Polityka głasnosti podważyła również pozycję Komsomołu, co spowodowało masowe występowanie młodzieży z tej organizacji. W tym okresie powstało szereg młodzieżowych organizacji nieformalnych. Szczególnie wysoką aktywnością społeczno-polityczną wyróżniali się studenci. 19 października 1987 r. w klubie Leśno-Technicznego Instytutu Lwowskiego młodzież zajmująca się od wiosny 1987 r. odnowieniem zabytków cmentarza Łyczakowskiego założyła „Stowarzyszenie Lwa”, które skupiło się na kwestiach kultury, historii, ekologii (Муравський, 2006, s. 140). 25 maja 1989 r. studenci lwowskich wyższych uczelni założyli

3 Za nieformalne ugrupowania i organizacje uważano zrzeszenia obywateli odbiegające programowo od głównych założeń ideologii marksistowsko-leninowskiej, funkcjonujące w latach 1987-1990 w ówczesnych republikach ZSRR. Brak podstawy prawno-ustrojowej ich funkcjonowania stawiał je w pozycji organizacji nieformalnych. 
Bractwo Studenckie miasta Lwowa (Bractwo). Ośrodki Bractwa zakładano w poszczególnych uczelniach Lwowa. Jesienią 1989 r. struktury Bractwa Studenckiego powstały w uczelniach Czerniowców, Iwano-Frankowska, Tarnopola, Łucka (Кулик, Голобуцька, Голобуцький, 2000). Bractwo Studenckie wywierało istotny wpływ na studentów zachodniej części Ukrainy. Do najważniejszych celów programowych należały: deideologizacja procesu nauczania; odrodzenie tradycji narodowego szkolnictwa wyższego; podniesienie narodowej i obywatelskiej świadomości studentów. Do swoich zadań Bractwo zaliczyło: ochronę praw studentów przed ich pogwałceniem przez administracje uczelni; rozwój myślenia demokratycznego; pielęgnację tradycji narodowych; ochronę zabytków historycznych (Багмет, Сорока, 2006, s. 148). 31 sierpnia 1989 r. Bractwo zorganizowało swój pierwszy mityng we Lwowie, podczas którego podniesione zostały następujące kwestie: wprowadzenie symboliki narodowej, rozwiązanie problemów polityki językowo-kulturowej na korzyść języka ukraińskiego, opracowanie nowej koncepcji oświaty opartej na doświadczeniu współpracy stowarzyszeń z młodzieżą w latach 1920-1930 (Головенько, Корнієвський, 1994, s. 75). Z kolei z inicjatywy środowisk studentów kijowskich 8-10 grudnia 1989 r. w Kijowie odbył się zjazd założycielski Ukraińskiego Związku Studentów (UZS) (Багмет, Сорока, 2006, s. 179). Ośrodki UZS funkcjonowały wówczas już w ponad dziesięciu miastach USRR (Доній, Синельников, 1999, s. 17). Podczas zjazdu została uchwalona deklaracja programowa. UZS określił się jako „niezależna społeczna organizacja studencka, która prowadzi aktywną działalność skierowaną na ochronę praw oraz interesów studentów, rozwój autonomii nauki i kultury, wychowanie narodowej inteligencji ukraińskiej, demokratyzację społeczeństwa oraz konstytuowanie suwerenności Ukrainy" (Доній, Синельников, 1999, s. 28, 64). Tworzono również młodzieżowe organizacje o orientacji stricte narodowej: latem 1989 r. młodzi członkowie Ukraińskiego Związku Helsińskiego (UZH) założyli regionalne ośrodki Związku Ukraińskiej Młodzieży (ZUM) (nawiązującego do tradycji organizacji młodzieżowej założonej w 1925 r., która po II wojnie światowej działała na emigracji); w maju 1990 r. został utworzony Związek Niezależnej Młodzieży Ukraińskiej (ZNMU).

4 marca 1990 r. odbyły się wybory do Rady Najwyższej USRR. Wybory te odbyły się w warunkach „względnego” monopolu KPU-KPZR, gdyż de facto działało wiele organizacji narodowo-demokratycznych, jednak de jure funkcjonował system jednopartyjny. Zarówno w Konstytucji 
$\mathrm{ZSRR}^{4}$, jak i USRR pozostawał przepis o monopolu partii komunistycznej ${ }^{5}$, wielopartyjność nie została jeszcze zalegalizowana, mimo polityki głasności czynnik cenzury w środkach masowego przekazu był istotny, a główne mass media w USRR pozostawały pod kontrolą partii komunistycznej. W celu udziału w wyborach do Rady Najwyższej USRR liderzy ukraińskich ugrupowań narodowych 18 listopada 1989 r. utworzyli Blok Demokratyczny, do którego weszły 43 organizacje (w tym LRU). W wyniku wyborów do Rady Najwyższej USRR według stanu z 19 marca 1990 r. wybrano 443 deputowanych, jeszcze 6 deputowanych wyłoniono w kwietniu tego roku (Baluk, 2006, s. 267). Z wybranych deputowanych $85 \%$ było członkami KPZR ${ }^{6}$, wśród nich 93 posłów posiadało stanowiska w aparacie partyjnym różnego szczebla (Ковалева, 1999, s. 16). Demokratyczny Blok uzyskał 111 mandatów (Камінський, 1990, s. 605) i podjął decyzję o przejściu do „konstruktywnej opozycji” wobec większości komunistycznej, powołując 6 czerwca 1990 r. opozycyjną parlamentarną grupę deputowanych „Rada Ludowa” (zrzeszyła 125 deputowanych). Przeciwwagę dla „Rady Ludowej” stanowiła utworzona 1 czerwca 1990 r. komunistyczna większość parlamentarna, grupa „O Radziecką Suwerenną Ukrainę”, w skrócie - „grupa 239” (tylu deputowanych weszło w jej skład).

Niepodległościowe ruchy $\mathrm{w}$ poszczególnych republikach ZSRR (ogłoszenie przez republiki nadbałtyckie deklaracji o wznowieniu niepodległości, uchwalenie przez republiki ZSRR deklaracji o suwerenności państwowej) spowodowały proces przygotowania nowej umowy o Związku Radzieckim. W dniu uchwalenia Deklaracji o państwowej suwerenności Rosyjskiej Federacyjnej Socjalistycznej Republiki Radzieckiej 12 czerwca 1990 r. Rada Federacji ZSRR podjęła decyzję o utworzeniu grupy roboczej, która miała opracować nową umowę o Związku Radzieckim. 16 lipca 1990 r. Rada Najwyższa USRR uchwaliła Deklarację o państwowej suwerenności Ukraińskiej Socjalistycznej Republiki Radzieckiej. Według

47 lutego 1990 r. plenum KC KPZR podjęło decyzję o anulowaniu art. 6 Konstytucji ZSRR z 1977 r. Z kolei III Zjazd Deputowanych Ludowych ZSRR (12-15 marca 1990 r.) dopiero 14 marca 1990 r. anulował art. 6 Konstytucji ZSRR stanowiący o monopolu KPZR w życiu społecznym.

5 Rada Najwyższa USRR anulowała art. 6 Konstytucji USRR z 1978 r. dopiero 24 października 1990 r.

6 Znaczna część umiarkowanych działaczy opozycyjnych pozostawała wówczas jeszcze w szeregach KPU-KPZR. 
Deklaracji USRR powinna była utworzyć własny system finansowy, wojsko oraz system bezpieczeństwa, władza na Ukrainie miała należeć do jej ludu (Деклараиія).

LRU był przeciwny podpisaniu przez Ukrainę nowej umowy o Związku Radzieckim. W związku z tym we wrześniu 1990 r. w szeregu miast USRR (Kijowie, Lwowie, Ługańsku, Żytomierzu, Czernihowie, Równym i innych) LRU zorganizował mityngi, podczas których domagał się od władz niezawierania nowej umowy o Związku Radzieckim, a także utworzenia własnego wojska ukraińskiego (Бойко, 2003, s. 83-84). Antykomunistyczna parlamentarna grupa deputowanych „Rada Ludowa” obwiniała rząd o nieprzestrzeganie Deklaracji o państwowej suwerenności USRR. „Rada Ludowa” domagała się dymisji ówczesnego przewodniczącego Rady Najwyższej Leonida Krawczuka oraz prezesa Rady Ministrów USRR Witalija Masoła, rozwiązania KPZR, rezygnacji z podpisania przez władze ukraińskie nowej umowy o Związku Radzieckim (Мицик, Бажан, Власов, 2008). „Rada Ludowa” wezwała obywateli do udziału 1 października 1990 r. (pierwszy dzień drugiej sesji Rady Najwyższej USRR) w ogólnoukraińskim strajku, w celu wyrażenia sprzeciwu wobec podpisania przez USRR nowej umowy o Związku Radzieckim, w którym według oficjalnych danych wzięło udział jedynie 10 tys. z $25 \mathrm{mln}$ pracowników w skali republiki (Бойко, 2003, s. 84). Należy zatem zgodzić się z ukraińskim historykiem O. Bojkiem, że „od prawdziwego nokautu politycznego opozycję uratowała studencka młodzież” (Бойко, 2003, s. 85), która rozpoczęła 2 października 1990 r. „rewolucję na granicie”.

\section{2. „Rewolucja na granicie” jako wyraz podmiotowości społeczno-politycznej ukraińskich studentów końca lat 80. i początku 90. XX w.}

Pod koniec 1989 - początek 1990 r. UZS i Bractwo Studenckie zorganizowały i przeprowadziły szereg akcji protestacyjnych, których głównym celem była deideologizacja i demilitaryzacja procesu nauczania na uczelniach (Муравський, 2008, s. 85). Główną akcją zorganizowaną przez Bractwo i UZS była jednak „rewolucja na granicie”. Należy do najbardziej spektakularnych działań protestacyjnych okresu „,demokracji mityngowej”. Idea organizacji akcji nieposłuszeństwa obywatelskiego została ogłoszona podczas obchodów 500 rocznicy kozactwa ukraińskiego, które odbyły się 1-5 sierpnia 1990 r. na Zaporożu. Młodzież zaplanowała sze- 
reg przedsięwzięć: głodówkę, mityngi, demonstracje, strajki (Бойко, 2003, s. 85). Liderami protestacyjnej akcji studentów byli: Markijan Iwaszczyszyn - prezes Bractwa Studenckiego, Ołeś Donij - prezes kijowskiego UZS oraz Oleg Barkow - prezes UZS Dnieprodzierżyńska.

Organizacje młodzieżowe przedstawiły pięć postulatów, których spełnienia domagały się podczas akcji protestacyjnej od władz komunistycznych. UZS domagał się: 1) przedterminowego rozwiązania Rady Najwyższej USRR i rozpisania nowych, całkowicie demokratycznych wyborów parlamentarnych nie później niż jesienią 1991 r. (studenci uważali, iż skład Rady Najwyższej wybranej w 1990 r. nie odzwierciedlał woli ludu ukraińskiego); 2) uchwalenia ustawy o nacjonalizacji mienia KPU oraz Komsomołu; 3) uniemożliwienia podpisania nowej umowy o Związku Radzieckim. Członkowie Bractwa Lwowskiego dodali jeszcze dwa, kolejne postulaty: 4) odbywanie powszechnej służby wojskowej na terytorium Ukrainy; 5) dymisja prezesa Rady Ministrów USRR Witalija Masoła (Бойко, 2001, s. 40). Studenci domagali wprowadzenia do Konstytucji zmian, uzgodnienia Ustawy Zasadniczej z Deklaracja o państwowej suwerenności Ukraińskiej SRR. Postulaty te zostały zawarte w apelu głodujących studentów do młodzieży Ukrainy. Apel zawierał zdecydowane wezwanie do ludzi młodych: „Przyjaciele! Przyszedł czas na dokonanie wyboru: albo wywalczymy niezależną i demokratyczną Ukrainę, albo nadal pozostaniemy kolonią imperium, ubogimi duchowo, denacjonalizowanym narodem. Żeby później nie przypominać słów Wieszcza (Tarasa Szewszenki): «Patrzyliśmy i milczeli, milcząc czesaliśmy czuby, niemi, podli niewolnicy». Wzywamy wszystkich do poparcia naszej akcji. Los naszej Ojczyzny zależy od nas wszystkich. Niech dopomoże nam Pan Bóg!" (3i сnогаdis).

Akcje protestacyjne studentów rozpoczęły się 2 października $1990 \mathrm{r}$. od ogłoszenia głodówki przez około 40 członków UZS i Bractwa Studenckiego na placu Rewolucji Październikowej. Pojawiły się tam transparenty z postulatami i hasłami studentów, zostało założone miasteczko namiotowe. Tegoż dnia odbyło się posiedzenie rady Kijowa na czele z pełniącym obowiązki przewodniczącego Oleksandrem Mosijukom przedstawicielem Bloku Demokratycznego. Podczas posiedzenia studentom zezwolono na przeprowadzenie masowych akcji protestu na czterech placach w centrum Kijowa (Кулик, Голобуцька, Голобуцький, 2000).

Według wspomnień W. Kipiani studenci na początku głodówki określili miasteczko namiotowe założone na placu Rewolucji Październikowej jako „terytorium wolne od komunizmu” (Кіпіані, 2010). Miasteczko na- 
miotowe nie powstawało chaotycznie, lecz, jak twierdzą O. Donij i Oleg Synelnykow, według stricte określonego planu. Namioty były rozbijane szeregami, zachowano określony dystans między nimi. W miasteczku postawiono namioty: głównego sztabu akcji, służby medycznej i prasowej. Miasteczko namiotowe, w którym głodowali studenci, zostało ogrodzone sznurami. Wejść do niego można było wyłącznie na podstawie przepustek (Коній, Синельников, 1999, s. 93).

Liczba głodujących studentów rosła, 3 października 1990 r. w głodówce brało udział 137 osób z Kijowa, Lwowa, Dniepropietrowska, Iwano-Frankowska oraz innych miast, 4 października głodowało już 151 osób, 9 października - 180 osób, 16 października liczba głodujących stanowiła 298 osób (Кулик, Голобуцька, Голобуцький, 2000). Uczestniczący w akcji na głowach przywiązali białe wstążki z napisem „głoduje”, natomiast studenci odpowiedzialni za logistykę i ochronę mieli na głowach czarne wstążki. Według danych Ministerstwa ds. Wyższej i Średniej Specjalnej Oświaty USRR w skali całej republiki w protestach wzięło udział prawie 100 tys. studentów (w tym okresie liczba studentów w USRR wynosiła 510 tys.), w tym w uczelniach stołecznych około 30 tys. studentów dziennych (Бойко, 2001, s. 42). W głodówce uczestniczyli nie tylko przedstawiciele Bractwa Studenckiego i UZS, a także członkowie ZNMU i innych organizacji młodzieżowych.

Protestujący studenci rywalizowali ze sobą w kreowaniu haseł i przysłów dotyczących KPZR, KPU, rzeczywistości komunistycznej: np. „Sierp i młot na złom”, „Głodujemy dzień i noc, doprowadził nas do tego Illicz (Lenin)”, „Czarnobyl - świetlana przyszłość dla całej ludzkości” (Окаринський, 2010, s. 200). Organizowali happeningową zbiórkę pieniędzy na „rewolucję światową”, a także na bilet do Moskwy dla Leonida Krawczuka, ówczesnego przewodniczącego Rady Najwyższej USRR. Jeden ze studentów wyrażając metaforycznie istotę nowej umowy o Związku Radzieckim zakuł się w żelazne kajdany (Доній, 1995, s. 41-42). Protestujący rwali i palili legitymacje komsomolskie, dzienniki „Prawda”, „Prawda Ukrainy”, „Radziecka Ukraina” (Поровський, 2009, s. 275). Głodujących studentów wspierali wykonawcy poezji śpiewanej: Maria Burmaka, Eduard Dracz, Oleg Pokalczuk i inni (Доній, 1995, s. 37). Solidaryzując się z głodującą młodzieżą w Kijowie protesty i strajki organizowali studenci uczelni Lwowa, Iwano-Frankowska, Sum, Winnicy i innych miast USRR.

Należy podkreślić, że parlamentarna opozycja antykomunistyczna nie uczestniczyła w organizacji „rewolucji na granicie”, a także nie udzieliła jej szerokiego poparcia. Począwszy od pierwszych dni akcji do studentów 
przychodzili przedstawiciele antykomunistycznej opozycji - deputowani Rady Najwyższej, członkowie demokratycznej grupy „Rada Ludowa”. Niektórzy proponowali pomoc w kontaktach z komunistycznymi władzami, inni z kolei usiłowali wymusić na studentach rezygnację z postulatu przeprowadzenia przedterminowych wyborów parlamentarnych, gdyż w ich opinii nie była to kwestia pierwszorzędna (Кіпіані, Українська). W sytuacji eskalacji napięcia między władzami a studentami 10 października 1990 r. nieliczna grupa deputowanych z „Rady Ludowej” (Wiktor Bed', Stepan Chmara, Łewko Horochiwśkyj, Wiktor Kolineć, Ołeksandr Hudyma, Mychajło Horyń i inni) ogłosiła głodówkę w celu poparcia żądań studentów (Кулик, Голобуцька, Голобуцький, 2000). Do strajku głodowego studentów dołączyło łącznie 11 deputowanych ludowych (Литвин, 1993, s. 114). Deputowany W. Bed' odczytał apel parlamentarzystów, którzy podjęli się głodówki: „[...] Nie mając możliwości oddziaływać na wyniki posiedzeń sesyjnych Rady Najwyższej popieramy postulaty głodujących studentów i ogłaszamy o swoim udziale w proteście głodowym od 10 października 1990 roku. Zwracamy się do narodu Ukrainy o wsparcie tych wymagań" (Студенти).

Natomiast komunistyczna większość na początku bardzo sceptycznie reagowała na protesty studenckie, tłumacząc je jako wyraz maksymalizmu młodzieżowego, skutek braku doświadczenia życiowego. Komunistyczni parlamentarzyści negatywnie zareagowali jednak na postulat studentów, dotyczący przedterminowego rozwiązania Rady Najwyższej USRR, w tej sprawie skierowali nawet list otwarty do głodujących studentów, obwiniając ich o wywieranie presji na deputowanych ludowych (Мандрик, 2012, s. 124). W czwartym dniu głodówki 5 października 1990 r. do miasteczka namiotowego przyszedł L. Krawczuk. Spotkał się on z liderami akcji studenckiej O. Donijem i M. Iwaszczyszynym w obecności telewizji. Spotkanie doprowadziło jedynie do wzrostu liczby protestujących studentów (Доній, Синельников, 1999, s. 94). Liderzy studentów przedstawili L. Krawczukowi swoje postulaty, ów z kolei stosował taktykę uników nie odnosząc się konkretnie do wypunktowanych przez nich kwestii. Studenci jednak zachowywali stanowczość, domagając się od władz komunistycznych realizacji postulatów. Przede wszystkim usiłowali przedstawić je społeczeństwu i uzyskać jego poparcie. Studenci komunikowali się z zagranicznymi środkami przekazu masowego, informując społeczność zachodnią o swoim stanowisku społeczno-politycznym. Protestujących studentów wspierała diaspora ukraińska. 10 października 1990 r. studenci zorganizowali manifestację, w której wzięło udział ok. 10 tys. osób 
(Кулик, Голобуцька, Голобуцький, 2000). Podczas tej manifestacji studenci zablokowali ruch drogowy na placu Chreszczatyk, okupowali siedzibę państwowej telewizji i radia USRR. Protestujący w 10 minutowej audycji radiowej przedstawili swoje postulaty. Blokada głównych ulic Kijowa miała miejsce $\mathrm{w}$ trakcie całej akcji protestacyjnej. Idąc centralnymi ulicami studenci skandowali hasła: „Precz z Masołem i Krawczukiem!”, „Dymisja!”, „Komunistów pod sąd!” (Поровський, 2009, s. 275). Z kolei podczas mityngu 12 października 1990 r. studenci przyjęli dwie rezolucje. W pierwszej wezwali do wywarcia „demokratycznej presji” na Radę Najwyższą poprzez manifestacje i strajki. W tej rezolucji podkreślili, że ,realizacja postulatów oznaczałaby orzeczenie wyroku śmierci dla systemu totalitarnego", w związku z tym parlament z komunistyczną większością nie podda się dobrowolnie takiemu werdyktowi. W drugiej rezolucji domagali od rządzących zaprzestania dezinformowania obywateli na temat akcji studenckiej i udostępnienia liderom protestu czasu antenowego na żywo w telewizji republikańskiej. W przypadku niewykonania przez władzę rezolucji, studenci zapowiedzieli podjęcie bardziej aktywnych działań (Доній, Синельников, 1999, s. 96-97). 14 października 1990 r. strajk rozpoczęli studenci większości uczelni Kijowa. Przełomowym dniem akcji był 15 października 1990 r., gdy w protestach wzięło udział ok. 100 tys. osób (studenci uczelni, uczniowie techników, szkół zawodowych i ogólnokształcących) (Бобровнік, 2008, s. 366-367). Tego dnia protestujący zablokowali siedzibę parlamentu, główne gmachy uczelni kijowskich. Dla ochrony budynku parlamentu przed protestującą młodzieżą ściagnięto milicję i wojsko (Поровський, 2009, s. 275). Ówczesny deputowany opozycyjny Mykoła Porowśkyj wspomina, że studenci przynieśli do budynku Rady Najwyższej dużą flagę niebiesko-żółtą gdzie przekazali ją deputowanym z „Rady Ludowej”, jednak większość komunistyczna zablokowała przejście uniemożliwiając wniesienie flagi (Поровський, 2009, s. 277). Pod presją „tłumu młodzieży” prezydium Rady Najwyższej USRR udostępniło mównicę parlamentu liderowi studenckiej akcji protestacyjnej O. Donijowi. Podczas swego wystapienia na posiedzeniu parlamentarnym O. Donij zażądał od przewodniczącego Rady Najwyższej obiektywnej transmisji protestów studenckich z placu Rewolucji Październikowej, umożliwienia studentom zwrócenia się do społeczeństwa, przedstawienia swojego stanowiska za pośrednictwem telewizji (3acida$н н я)$. W efekcie protestów władze zezwoliły na jedną godzinną audycję w telewizji państwowej z udziałem liderów akcji protestacyjnej (Доній, О. Синельников, 1999, s. 98). W jej trackie liderzy studentów uargumen- 
towali swoje postulaty wobec władz i wezwali do strajku generalnego. 16 października 1990 r., Rada Najwyższa USRR postanowiła odnieść się do żądań studentów, w tym celu została powołana komisja uzgodnieniowa. W skład komisji weszło 5 deputowanych reprezentujących komunistyczną większość, a także 5 deputowanych - przedstawicieli parlamentarnej opozycji antykomunistycznej oraz 5 liderów protestów studenckich (Кулик, Голобуцька, Голобуцький, 2000).

\section{Wyniki ,rewolucji na granicie”}

Po zapoznaniu się ze sprawozdaniem komisji uzgodnieniowej, 17 października 1990 r. parlament przyjął Postanowienie Rady Najwyższej Ukraińskiej SRR o rozpatrzeniu postulatów studenckich, którzy głoduja w mieście Kijowie od 2 października 1990 roku. Za Postanowieniem zagłosowało 314 deputowanych, a tylko 38 przeciw (Кулик, Голобуцька, Голобуцький, 2000).

W odniesieniu do kwestii przeprowadzenia przedterminowych wyborów do Rady Najwyższej parlament postanowił „podczas drugiej sesji Rady Najwyższej USRR uchwalić ustawę o referendach w Ukraińskiej SRR, ustawę o zrzeszeniach obywateli i organizacjach w Ukraińskiej SRR, ustawę o statusie deputowanego ludowego Ukraińskiej SRR [...], ustawę o wyborach w Ukraińskiej SRR na podstawie wielopartyjnej" (Постанова). Deputowani postanowili również w tym zakresie w $1991 \mathrm{r}$. przeprowadzić w USRR referendum w sprawie wotum zaufania wobec parlamentu, i już na podstawie jego wyników podjąć decyzję dotyczącą przeprowadzenia przedterminowych wyborów. Parlamentarzyści podjęli decyzję, że za granicami republiki obywatel USRR może odbywać służbę wojskową tylko za zgodą własną. W tym celu postanowiono uchwalić do 31 grudnia 1990 r. ustawę o powszechnym obowiązku służby wojskowej obywateli Ukrainy na terytorium republiki oraz ustawę o alternatywnej służbie wojskowej, a także powołać niezbędne dla realizacji tego zadania organy państwowe (Постанова). W odniesieniu do kwestii nacjonalizacji mienia partii komunistycznej i Komsomołu na terytorium Ukrainy, Rada Najwyższa USRR postanowiła przeanalizować wnioski Arbitrażu Państwowego USRR, Ministerstwa Sprawiedliwości USRR i Komitetu Państwowego USRR ds. gospodarki dotyczące tej sprawy i do 1 grudnia 1990 r. powołać czasową komisję Rady Najwyższej USRR, która nią się zajmie (Постанова). W zakresie zawarcia nowej umowy o Związku Ra- 
dzieckim deputowani 12 kadencji Rady Najwyższej USRR postanowili „skierować wszelkie wysiłki [...] na zbudowanie suwerennego ukraińskiego państwa prawa, uchwalenie Konstytucji republiki” (Постанова). Dopóki zatem powyższe zadania nie są zrealizowane, zawarcie nowej umowy o Związku Radzieckim uznano za przedwczesne. W celu utworzenia podstawy prawnej dla wykonania powyższego Postanowienia parlament zapowiedział do 30 listopada 1990 r. uzgodnienie funkcjonującej Konstytucji z przepisami Deklaracji o państwowej suwerenności Ukrainy (Постанова).

Z kolei 23 października 1990 r. Rada Najwyższa USRR przyjęła dymisję prezesa Rady Ministrów W. Masoła. Jednak 16 czerwca 1994 r. na propozycję ówczesnego prezydenta L. Krawczuka, W. Masoł został ponownie powołany przez parlament na stanowisko premiera (Gabinetu Ministrów Ukrainy). Poza tym władze USRR nadal brały udział w procesie opracowania nowej umowy o Związku Radzieckim (Медведев, 1994, s. 181-182). Umowa o Związku Suwerennych Państw miała być podpisana 20 sierpnia 1991 r. Umowa ta nie została podpisana z powodu nieudanej próby „przewrotu państwowego”, tzw. puczu, do którego doszło w Moskwie 19-21 sierpnia 1991 r. Studencka „rewolucja na granicie” nie przyczyniła się zatem do niepodpisania przez USRR nowej umowy o Związku Radzieckim. Postanowienie dotyczące przedterminowych wyborów do Rady Najwyższej również nie zostało wykonane. LRU podniósł ideę przedterminowych wyborów parlamentarnych dopiero w sierpniu 1992 r., wówczas nie udało się jednak zebrać niezbędnych do tego 3 mln podpisów. Rada Najwyższa wybrana w USRR funkcjonowała w niepodległej Ukrainie. Wybory parlamentarne odbyły się dopiero w 1994 r. na tle głębokiego kryzysu gospodarczego, gdy obywatele preferowali partie lewicowe, genetycznie związane z komunizmem. Opozycja antykomunistyczna, nie wspierając postulatów protestujących studentów w sprawie przeprowadzenia przedterminowych wyborów w 1991 r. na „fali uniesienia narodowego", wykazała się więc krótkowzrocznością. Realizacja przez władze Ukrainy postulatu dotyczącego służby wojskowej w pełnym zakresie miała miejsce po uchwaleniu Aktu Niepodległości Ukrainy 24 sierpnia 1991 r. i nie wiązała się z żądaniami protestujących studentów.

\section{Wnioski}

Podsumowując, należy zgodzić się z uczestnikami „rewolucji na granicie" O. Donijem, O. Synelnykowym, iż główne zwycięstwo studentów 
leżało w płaszczyźnie psychologicznej - młodzież stała się podmiotem procesu społeczno-politycznego ,samodzielnie organizując się i doprowadzając swoje działania do logicznego końca" (Доній, Синельников, 1999, s. 102). Znalazło to swoje odzwierciedlenie w kolejnych znaczących dla historii i systemu politycznego Ukrainy wydarzeniach - akcji protestacyjnej „Ukraina bez Kuczmy” w latach 2000-2001, „pomarańczowej rewolucji” w 2004 r. oraz Euromajdanie - „rewolucji godności” w latach 2013-2014, w których młodzież była jednym z głównych podmiotów. Należy stwierdzić, że „rewolucja na granicie” zapoczątkowała na Ukrainie cały cykl „rewolucji” jako działań skierowanych na ustanowienie systemu rządów prawa, wprowadzenie standardów demokracji zachodniej.

\section{Bibliografia}

Baluk W. (2006), Ksztaltowanie systemu partyjnego Ukrainy w okresie transformacji ustrojowej (1987-2004), Oficyna Wydawnicza Arboretum, Wrocław.

19 Всесоюзная конференция Коммунистичиской партии Советского Союза, 28 июня-1 июля 1988 г. Стенографический отчет: в 2-х томах, t. 2 (1988), Политиздат, Москва.

Багмет М., Сорока С. (2006), Комсомол та неформальні об'єднання України в період ,„перебудови”, „Політичний менеджмент”, nr 5.

Бобровнік Ю. (2008), Діяльність Української студентської спілки (1989-1991 рр.), „Наукові записки з української історії, nr 21.

Бобровнік Ю. (2009), Виникнення та діяльність Львівського студентського братства в Україні (1989-1994 рр.), „Український історичний збірник”, $\mathrm{nr} 12$.

Бойко О. (2001), Феномен жовтневої револючії 1990 року або чому альттернатива не стала реальністю, „Нова політика і час”, $\mathrm{nr} 4$.

Бойко О. (2002), Україна у 1985-1991 рр. Основні тенденції суспільно-політичного розвитку, ІПіЕНД, Київ.

Бойко О. (2003), Загострення політичної конфронтації в Украӥні: атака опозиції та контрнаступ консерваторів (серпень-грудень 1990 р.), „Сучасність", $\mathrm{nr} 1$.

Гарань О. (1993), Убити дракона: 3 історії Руху та нових партій Украӥни, Либідь, Київ.

Головенько В., Корнієвський О. (1994), Украйнський молодіжний рух: історія та сьогодення, Наукова думка, Київ.

Гончарук Г., Шановська О. (2004), Національна ідея і Народний Рух Украӥни, „Астропринт”, Одеса. 
Грицак Я. (2000), Нарис історії України. Формування модерної украӥнської нащії, „Генеза”, Київ.

Деклараџія про державний суверенітет, w: Національні відносини в Украӥні y XX cm. (1995), Наукова думка, Київ.

Доній О. (1995), Студентська революиія на граніті, Смолоскип, Тріумф, Київ.

Доній О., Синельников О. (1999), Історія УСС мовою документів і фактів (1989-1999), Смолоскип, Київ.

Закон СССР О выборах народных депутатов СССР, http://rusarchives.ru/statehood/ 09-27-zakon-vybory.shtml, 10.06.2013.

Засідання тринадияте. Сесійний зал Верховної Ради Української РСР. 15 жовтня 1990 року. 10 година. Головує Голова Верховної Ради Украӥнської РСР Кравчук Л.М., http://static.rada.gov.ua/zakon/sk11/BUL12/151090_13.htm, 22.06.2013.

Зі спогадів Петра Світличного, депутата Київради з 1990 року, http://www2.maidanua.org/news/for-print.php3?bn=maidan_lib\&key=1022708603, 25.05.2013.

Камінський А. (1990), На перехідному етапі. „Гласність”, „, перебудова” $i$,„демократизація” на Україні, Український вільний університет, Мюнхен.

Кіпіані В., Украӥнська революція чи р-еволючџія?, http://www.kipiani.org/plain.cgi?677, 25.05.2013.

Кіпіані В., Майдан Незалежності, „Українська правда” 4 X 2010, http://www.pravda.com.ua/photo-video/2010/10/4/5442478/, 30.05.2013.

Ковалева Е. (1999), От єлитизма через корпоратизм к плюрализму? Роль єлит в политических трансформациях в Украине, Open Society Institute, Mocква, http://rss.archives.ceu.hu/archive/00001026/01/27.pdf, 1.07.2013.

Кулик В., Голобуцька Т., Голобуцький О. (2000), Молода Украӥна: сучасний організований молодіжний рух та неформальна ініціатива, ЦДПГС, Київ, http://golob.narod.ru/volchet.html, 8.04.2013.

Литвин В. (1993), Політична арена Украӥни. Дійові особи та виконавціі, Абрис, Київ. Студенти і Кравчук, http:/www.mr.org.ua/golod/student\&Kravchuk.htm, 29.05.2013.

Мандрик М. (2012), Студентська ініціатива як компонент сучасної молодіжної активності, „Гілея. Історичні науки. Філософські науки. Політичні науки", nr 62(7).

Медведев В. (1994), В команде Горбачева: взгляд изнутри, Былина, Москва.

Медведев Р. (2010), Советский Союз. Последние годы жизни. Конеи советской империи, АСТ, Москва, http://litrus.net/book/read/2516?p=46, 13.05.2013.

Мицик Ю., Бажан О., Власов В. (2008), Історія України, Видавничий дім „КиєвоМогилянська академія”, Київ, http://news-zakon.com/istorija-ukrayini/112-juamitsik-ogbazhan-vsvlasov-istorija-ukrayini/2982-protses-perebudovi-v-srsr-ta-jogo-naslidki-dlja-ukrayini.html, 9.06.2013. 
Муравський О. (2006), Молодіжний рух в Украйні на зламі 80-х-90-х років XX ст.: політологічний аспект, „Українська національна ідея: реалії та перспективи розвитку", $\mathrm{nr} 18$.

Муравський О. (2008), Студентство Украӥни за демократичне вирішення питання військової підготовки наприкіниі 80-x-початку 90-х років XX cm., „Військово-науковий збірник: Збірник наукових праць”, nr 10.

О демократизации советского общества и реформе политической системь, http://ru-90.ru/content/резолюции-хіх-всесоюзной-конференции-кпсс, 13.05.2013.

Окаринський В. (2010), Риси контркультури у суспільних процесах періоду «перебудови» в Україні (друга половина 1980-х-1991 рр.), „Наукові записки Тернопільського національного педагогічного університету імені Володимира Гнатюка (Серія: Історія)", nr 1.

O перестройке и кадровой политике партии. Доклад Генерального секретаря ЦК КПСС М. С. Горбачева 27 января 1987 года. Материаль Пленума Центрального Комитета КПСС 27-28 января 1987 года, Политиздат, Москва 1987, http://soveticus5.narod.ru/88/od1987.htm, 21.04.2013.

Поровський М. (2009), Тільки Рухом життя обіймеш..., ПП Лапсюк, Рівне.

Постанова Верховної Ради Української РСР Про розгляд вимог студентів, які проводять голодування в м. Києві з 2 жовтня 1990 року, „Відомості Верховної Ради УРСР” 1990, nr 45, poz. 604, http://zakon4.rada.gov.ua/ laws/show/402-12, 30.05.2013.

Три дні вересня (Матеріали установчого з’їду Народного Руху України за перебудову) (2000), Інститут української археографії та джерелознавства ім. М. Грушевського НАН України, Київ.

\section{The student 'granite revolution' in the context of the socio-political transformations in the Ukrainian Soviet Socialist Republic}

\section{Summary}

The paper analyses the student campaign of civil disobedience organised in October 1990 and later named 'the granite revolution.' During the 'granite revolution,' students demonstrated their socio-political awareness, taking decisions of key importance at that time. The author of the paper also analyses the outcomes of the 'granite revolution' and its significance for further socio-political developments in Ukraine. 